\title{
A Comparison of Healthy Infants and Adults with Respect to Indirect Microparticle Activity and the Parameters of the Thrombin Generation Test
}

\author{
Sağlıkı Süt Çocukları ve Erişkinlerin Indirekt Mikropartikül Aktivitesi ve Trombin Jenerasyon \\ Parametrelerine Göre Karşılaştııılması
}

\author{
Filiz Şimşek Orhon¹, Nejat Akar², Yonca Eğin², Betül Ulukol¹, Sevgi Başkan¹ \\ ${ }_{1}^{1}$ Ankara University Faculty of Medicine, Department of Pediatrics, Divisions of Social Pediatrics, Ankara, Turkey \\ ${ }^{2}$ Ankara University Faculty of Medicine, Department of Pediatrics, Divisions of Pediatric Molecular Genetics, Ankara, Turkey
}

\section{To the Editor,}

Microparticles express phospholipids and support thrombin generation, which increases with age $[1,2]$.

In a recently published study, we showed age-dependent changes in thrombin generation parameters in a healthy infant population aged 1-24 months [3]. The aim of this present study was to compare the levels of both indirect microparticle activity and thrombin generation parameters of healthy infants from our recent study to those of a healthy adult population. The adult population consisted of medical students of the Ankara University School of Medicine. Blood was collected into tubes containing $1 \mathrm{~mL}$ of $0.109 \mathrm{M}$ trisodium citrate. For indirect microparticle activity, plasma samples were studied using the STA-PROCOAGPPL Kit (Diagnostica Stago Inc., Asnières sur Seine, France). Plasma samples were measured using thrombin generation kits, including a Thrombin Calibrator, PPP-Reagent $5 \mathrm{pM}$, and the FluCa-Kit (Diagnostica Stago). Thrombin generation curves were calculated using Thrombinoscope software (Thrombinoscope BV, Maastricht, the Netherlands). The following parameters were derived from the curves: lag time (LT, min), time to initiation of thrombin generation; endogenous thrombin potential (ETP, $\mathrm{nmol} / \mathrm{L} / \mathrm{min}$ ), area under the thrombin generation curve; peak thrombin activity (peak, nmol/L); and time to peak thrombin generated (TTP, min). Statistical analysis was performed using Statistical Package for the Social Sciences 16.

A total of 58 healthy adults (23 males and 35 females; mean age: $23.2 \pm 0.4$ years) were admitted to the study. In our recent study, 85 healthy infants ( 51 males and 34 females; mean age: $12.6 \pm 8.3$ months) were studied. The indirect microparticle activity in the infant group was significantly lower than that of the adult group $(p<0.001)$. The ETP and peak levels in the infant group were significantly lower than those of adults. Furthermore, the TP levels of the adult group were lower than those of infants $(p=0.001)$ (Table 1$)$.
Physiologic concentrations of coagulation proteins gradually increase after birth [4]. Karlaftis et al. showed that procoagulant phospholipid activity was increased in neonates and decreased in children aged 1-16 years [5]. We show that the levels of indirect microparticle activity are increased in healthy adults as compared to healthy infants. This may suggest that aging is correlated to an increase in the indirect microparticle activity, and also possibly to its procoagulant and proinflammatory features.

Thrombin generation is influenced by different variables like age, sex, body mass index, genetic factors, and acquired conditions $[6,7]$. In a previous study, the ETP values of children were found to be lower than those of adults [8]. Positive correlations were found for age versus thrombin generation parameters in calibrated automated thrombography in two recent studies $[9,10]$. We showed that ETP and peak levels were higher in adults as compared to infants. Thus, we suggest that ETP and peak levels, the main parameters of thrombin generation, increase gradually from infancy to adulthood. As for limitations, our adult group was not adequate for representing all ages of the adult population and there was a difference between the groups

Table 1. Data on indirect microparticle activity and thrombin generation parameters of the study groups.

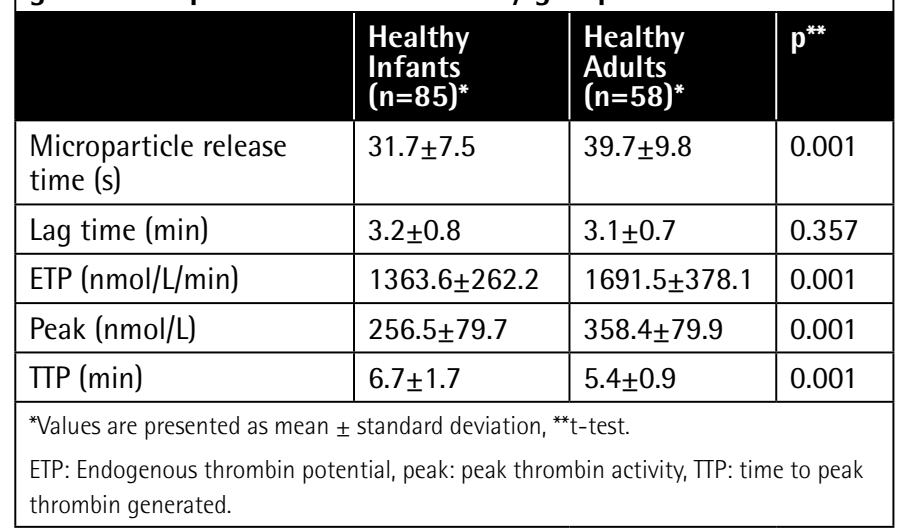


in terms of sex ratios. However, we may conclude that plasma from adults may be more procoagulant than that of infants. Our findings may confirm the presence of a regulation mechanism in the coagulation parameters throughout the course of life.

Keywords: Infant, Adult, Microparticle, Thrombin

Anahtar Sözcükler: Süt çocuğu, Erişkin, Mikropartikül, Trombin

Authorship Contributions

Study Conception and Design: Nejat Akar, Filiz Şimşek Orhon; Acquisition and Blood Collection: Filiz Şimşek Orhon, Sevgi Başkan; Laboratory Analysis: Yonca Eğin; Interpretation of Data: Nejat Akar, Filiz Şimşek Orhon; Literature Search: Filiz Şimşek Orhon, Betül Ulukol; Drafting and Writing: Filiz Şimşek Orhon.

Conflict of Interest: The authors of this paper have no conflicts of interest, including specific financial interests, relationships, and/or affiliations relevant to the subject matter or materials included.

Financial Disclosure: This study was supported in part by the Ankara University Research Fund.

\section{References}

1. Chironi GN, Boulanger CM, Simon A, Dignat-George F, Freyssinet JM, Tedgui A. Endothelial microparticles in diseases. Cell Tissue Res 2009;335:143-151.

2. Brummel-Ziedins KE, Everse SJ, Mann KG, Orfeo T. Modeling thrombin generation: plasma composition based approach. J Thromb Thrombolysis 2014;37:32-44.

3. Orhon FS, Egin Y, Ulukol B, Baskan S, Akar N. Evaluation of indirect microparticle activity and parameters of thrombin generation test in healthy infants. Thromb Res 2014;133:281-284.

4. Kenet G, Krumpel A, Nowak-Gottl U. Bleeding issues in neonates, infants and young children. Thromb Res 2009;123(Suppl 2):S35-S37.

5. Karlaftis V, Attard C, Summerhayes R, Monagle $P$, Ignjatovic V. The microparticle-specific procoagulant phospholipid activity changes with age. Int J Lab Hem 2014;36:e41-e43.

6. Castoldi E, Rosing J. Thrombin generation tests. Thromb Res 2011;127(Suppl 3):S21-S25.

7. Butenas $\mathrm{S}$, van't Veer $\mathrm{C}$, Mann KG. "Normal" thrombin generation. Blood 1999;94:2169-2178.

8. Haidl H, Cimenti C, Leschnik B, Zach D, Muntean W. Age-dependency of thrombin generation measured by means of calibrated automated thrombography (CAT). Thromb Haemost 2006;95:772-775.

9. Schneider T, Siegemund T, Siegemund R, Petros $S$. Thrombin generation and rotational thromboelastometry in the healthy adult population. Hamostaseologie 2015;35:181-186.

10. Wu J, Zhao HR, Zhang HY, Ge YL, Qiu S, Zhao J, Song Y, Zhao JZ, Lu SS. Thrombin generation increasing with age and decreasing with use of heparin indicated by calibrated automated thrombogram conducted in Chinese. Biomed Environ Sci 2014;27:378-384.

\title{
Comment: In Response to "Downgraded Lymphoma: B-Chronic Lymphocytic Leukemia in a Known Case of Diffuse Large B-Cell Lymphoma - De Novo Occurrence or Transformation"
}

\author{
Yorum: Cevap Olarak "Geriletilmiş Lenfoma: Diffüz Büyük B-Hücreli Lenfoma Olduğu Bilinen \\ Bir Olguda B-Kronik Lenfositik Lösemi - De Novo Oluşum veya Dönüşüm"
}

Burak Uz, Kadir Acar

Gazi University Faculty of Medicine, Department of Internal Medicine, Division of Adult Hematology, Ankara, Turkey

To the Editor,

We read the letter submitted by Gajendra et al. with deep interest [1]. The authors described a patient diagnosed with diffuse large B-cell lymphoma (DLBCL) non-germinal center B-cell type in 2002 who received 6 cycles of cyclophosphamide, adriamycin, vincristine, and prednisolone (CHOP) followed by radiotherapy. He was well for nearly 5 years, but subsequently his disease locally relapsed. Unfortunately, a planned intensive salvage regimen could not be given because the patient was lost to follow-up. In 2010, despite not being given any treatment modality, he presented with small lymphocytic lymphoma. Finally, 22 months thereafter, he was diagnosed with Rai stage IV chronic lymphocytic leukemia and 6 cycles of fludarabine, 